\title{
Kryzys Unii Gospodarczo-Walutowej jako przesłanka wydłużenia harmonogramu wypelniania przez Polskę kryteriów konwergencji
}

Dzień 1 stycznia 2012 r. to pierwsza zadeklarowana w dokumencie rządowym data wprowadzenia w Polsce euro ${ }^{1}$. Cel ten oparto na założeniu wypełnienia w 2011 r. kryteriów konwergencji i uchylenia przez Radę Europejską w stosunku do Polski derogacji ${ }^{2}$. Na przeszkodzie stanął jednak kryzys gospodarczy, zapoczątkowany na globalnych rynkach finansowych w 2007 r. Z perspektywy czasu można stwierdzić, iż ten sam kryzys, który uniemożliwił Polsce spełnienie ekonomicznych kryteriów z Maastricht, uwidocznił jednocześnie słabości Unii Gospodarczej i Walutowej oraz korzyści wynikające z posiadania statusu państwa objętego derogacją. Doświadczenia te powinny zatem wpłynąć na harmonogram wypełniania przez Polskę kryteriów konwergencji, który zostanie przyjęty w $\mathrm{Na}$ rodowym planie wprowadzenia euro.

Celem niniejszego artykułu jest wykazanie wpływu trwającego kryzysu na bilans korzyści i kosztów wynikających z wprowadzenia euro (pełnego uczestnictwa Polski w trzecim etapie Unii Gospodarczej i Walutowej) $)^{3}$ oraz implika-

* Dr Rafał Mroczkowski - Katedra Prawa Finansowego, Wydział Prawa i Administracji, Uniwersytet Gdański.

${ }^{1}$ Ministerstwo Finansów, Mapa drogowa przyjęcia euro przez Polskę. Materiat informacyjny, Warszawa 2008, www.mf.gov.pl/_files_/euro/raporty/rzadowe/2_mapa_drogowa_28_10_2008.pdf, www.mf.gov.pl/files_/euro/raporty/rzadowe/2_mapa_drogowa_28_10_2008.pdf, s. 3 .

2 Status państwa członkowskiego objętego derogacją określa art. 139 i n. Traktatu o funkcjonowaniu Unii Europejskiej - wersja skonsolidowana - Dz. U. C 115 z 9 maja 2008 r., s. 1-388 (dalej: TFUE).

${ }^{3}$ Unia Gospodarcza i Walutowa (Economic and Monetary Union; EMU) tworzona była w trzech etapach zgodnie z procedurami i harmonogramem określonymi w Traktacie ustanawiającym Wspólnotę Europejską (dalej: TWE). W pierwszym etapie (1.07.1990-31.12.1993) zlikwidowano ograniczenia w przepływie kapitału i płatności, w ramach realizacji wieloletnich programów osiągnięto wysoki stopień trwałej zbieżności (lasting convergence), w szczególności w zakresie stabilizacji cen, dyscypliny budżetowej i wprowadzenia rynku wewnętrznego. W ramach drugiego etapu (1.01.1994-31.12.1998) utworzono Europejski Instytut Walutowy, wprowadzono zakaz finansowania sektora publicznego przez banki centralne, zakaz uprzywilejowanego dostępu do instytucji 
cji tej tezy dla harmonogramu wypełniania przez Polskę kryteriów z Maastricht, w szczególności polegających na przesunięciu terminu przyjęcia euro bądź rezygnacji z określania tej daty na obecnym etapie.

\section{Wprowadzenie}

Europejska unia walutowa od początku była budowana jako projekt polityczny, będący zwieńczeniem procesu ekonomicznej integracji Europy i propagowany jako sztandarowy jej sukces. Jednocześnie okazało się, że projekt ten niedostatecznie uwzględniał różnice w zakresie poziomu rozwoju gospodarczego, konkurencyjności gospodarek, wydajności pracy, kultury prawnej i organizacyjnej w poszczególnych państwach strefy euro. $Z$ dzisiejszej perspektywy można zatem stwierdzić, iż Unia Gospodarcza i Walutowa jest u jej zarania obarczona ,grzechem pierworodnym", którego prawdziwa natura objawiła się w czasie ostatniego kryzysu gospodarczego. Kryzys ten, zwany już teraz wielkim, początkowo w latach 2007-2009 ujawnił się na rynkach finansowych, następnie w 2009 r. w realnej gospodarce, a poprzez impulsy z niej płynące - w sektorze publicznym, przybierając postać kryzysu fiskalnego. Ta ostatnia jego odsłona dotknęła w sposób szczególny państwa Unii Gospodarczej i Walutowej o najniższym poziomie realnej konwergencji ${ }^{4}$, względnie z niestabilnym systemem bankowym, dla których przyjęło się wymowne określenie PIGS, oparte na pierwszych literach angielskich nazw takich państw, jak: Portugalia, Irlandia, Grecja i Hiszpania. Do tego niechlubnego grona dołączyły Włochy, a w wyniku efektu zarażania kryzys rozlewa się na inne państwa, w tym stanowiące trzon Unii Gospodarczej i Walutowej, w szczególności na Francję i Holandię. W krajach tych kryzys stał się katalizatorem problemów, które nagromadzily się przez lata, w szczególności związanych z nadmiernym deficytem i długiem zarówno publicznym, jak i prywatnym, spadającą bazą podatkową, będącą efektem deindustrializacji i niekorzystnych tendencji demograficznych, malejącą konkurencyjnością gospodarek m.in. wskutek nieelastycznego rynku pracy oraz niestabilnym systemem bankowym. Dowodzi

\footnotetext{
finansowych oraz obowiązek unikania nadmiernego deficytu. Trzeci etap (1.01.1999-31.12.2001) obejmował przyjęcie przez państwa spełniające kryteria konwergencji jednolitej waluty i zaprowadzenie w ramach Europejskiego Systemu Banków Centralnych (ESBC) wspólnej polityki pieniężnej i walutowej oraz utworzenie nowego Mechanizmu Stabilizowania Kursów (ERM II). Dnia 1 stycznia 1999 r. 11 państw przyjęło euro w obrocie bezgotówkowym w charakterze waluty rozliczeniowej, zaś od 1 stycznia 2002 r. wprowadzono ją do obiegu, por. A. Jurkowska-Zeidler, Europejska Unia Walutowa, [w:] A. Drwiłło, D. Maśniak (red.), Leksykon prawa finansowego, Warszawa 2009, s. 110 i $n$.

${ }^{4}$ Podobieństwo gospodarek krajowych jest mierzone przy pomocy wskaźników makroekonomicznych i finansowych.
} 
to, iż pełne uczestnictwo w Unii Gospodarczej i Walutowej nie stanowi remedium na kryzysy gospodarcze i finansowe. Do zapewnienia stabilności finansowej i makroekonomicznej konieczna jest bowiem także odpowiednia polityka gospodarcza, w tym fiskalna, prowadzona na szczeblu krajowym.

W tych niekorzystnych warunkach makroekonomicznych Polska, która jako kraj objęty derogacją zachowała własną walutę i samodzielność w kreowaniu polityki pieniężnej, wydaje się we względnie korzystnym położeniu. Kurs złotego polskiego w stosunku do głównych walut w reakcji na wzrost awersji do ryzyka poddany został gwałtownej deprecjacji, co zwiększyło konkurencyjność polskich towarów i usług za granicą, i zmniejszyło ją w odniesieniu do towarów wwożonych do kraju, wspierając eksport i osłabiając opłacalność importu, co pozytywnie wpłynęło na poziom produktu krajowego brutto. Samodzielność w określaniu celów polityki pieniężnej i jej realizacji pozwoliła zaś na dostosowanie jej założeń do krajowych warunków makroekonomicznych. W efekcie tych i innych czynników Polska uniknęła recesji, która w roku 2009 oraz powtórnie na przełomie lat 2011 i 2012 dotknęła wiele państw strefy euro.

\section{Istota kryzysu Unii Gospodarczej i Walutowej oraz jego implikacje dla wprowadzenia w Polsce euro}

Kryzys Unii Gospodarczej i Walutowej można określić jako stan, w którym system gospodarczo-walutowy UE nie realizuje prawidłowo swoich funkcji, polegających w szczególności na zapewnieniu swobodnego i bezpiecznego przepływu kapitału i płatności pomiędzy państwami członkowskimi, a także w stosunku do państw trzecich, ułatwianiu pozyskiwania z rynków środków finansowych tak przez państwa, jak i przez przedsiębiorstwa, zapewnieniu zrównoważonego rozwoju gospodarczego państwom członkowskim.

Mając na uwadze powyższe aspekty, należy wskazać, iż objawami trwającego obecnie kryzysu są w szczególności:

- utrudnienia w dostępie do finansowania rynkowego przez niektóre państwa członkowskie w drodze emisji obligacji, objawiające się zmniejszonym popytem na te papiery wartościowe i rosnącym ich oprocentowaniem;

- utrudnienia w dostępie do kredytu dla przedsiębiorstw i obywateli, co przejawia się w zmniejszeniu akcji kredytowej;

- run na banki w państwach południa Europy;

- przenoszenie wkładów do banków z siedzibą w państwach członkowskich cechujących się stabilnym systemem bankowym;

- nagłe zmiany cen instrumentów na rynkach finansowych.

Zjawiska te z punktu widzenia zarówno poszczególnych państw, sektora przedsiębiorstw, jak i obywateli powodują istotne zmiany w bilansie korzyści i kosztów wynikających z przyjęcia wspólnej waluty, zmniejszając w krótkiej 
perspektywie te pierwsze i zwiększając te drugie ${ }^{5}$. Jest to szczególnie widoczne w odniesieniu do Polski, będącej importerem netto kapitału, co do której powszechnie formułowano oczekiwania, iż wprowadzenie euro ułatwi dostęp do finansowania na europejskich rynkach finansowych i obniży jego koszt. Stanowi to asumpt do podjęcia próby oceny wpływu kryzysu na poziom korzyści i kosztów wynikających z pełnego uczestnictwa w trzecim etapie UGW, związanych z wypełnieniem przez Polskę kryteriów konwergencji i przyjęciem wspólnej waluty.

Jeszcze w 2009 r. na podstawie zakrojonych na szeroką skalę badań prowadzonych z inicjatywy Narodowego Banku Polskiego bilans ten oceniany był jako korzystny, przy tym nad głównie krótkoterminowymi kosztami przeważały korzyści rosnące $\mathrm{w}$ długim okresie ${ }^{6}$. Na powyższą tezę nie wpłynęły zasadniczo pierwsze symptomy kryzysu fiskalnego $\mathrm{w}$ państwach sfery euro 7 . Podobne wnioski płyną z analiz prowadzonych na zlecenie Pełnomocnika Rządu ds. Wprowadzenia Euro przez Rzeczpospolitą Polską. W podsumowaniu dokumentu uzupełniającego do Ram strategicznych narodowego planu wprowadzenia euro, pt. Bilans korzyści i kosztów wprowadzania euro w Polsce w świetle najnowszych badań, wskazuje się, iż „z zestawienia szerokiego spektrum badań nad skutkami integracji ze strefą euro wynika, że proces ten powinien być dla Polski korzystny zarówno w krótkim, jak i w długim okresie. Należy przy tym zaznaczyć, że w długim okresie przewaga korzyści nad kosztami jest znacznie większa"s.

W chwili obecnej niezależnie od analizy zmieniającej się relacji rosnących kosztów do zmniejszających się korzyści należy uwzględnić ryzyko częściowego lub zupełnego rozpadu strefy euro i wystąpienia trudnego do przewidzenia, jeżeli chodzi o czas trwania i głębokość, kryzysu finansowego i gospodarczego?

${ }^{5}$ Z analiz prowadzonych przez Narodowy Bank Polski (NBP) jeszcze przed akcesją Polski do Unii Europejskiej wynika jednoznacznie pozytywny bilans korzyści i kosztów, por. Narodowy Bank Polski, Raport na temat korzyści i kosztów przystapienia Polski do strefy euro, Warszawa 2004, www.nbp.pl/publikacje/o euro/korzysci euro 2004.pdf, s. 9 i n.

${ }^{6}$ Najbardziej kompleksowym dokumentem analizującym korzyści i koszty wynikające $\mathrm{z}$ wprowadzenia $\mathrm{w}$ Polsce euro jest przygotowany $\mathrm{z}$ inicjatywy Narodowego Banku Polskiego i w ramach programu badawczego prowadzonego na jego zlecenie, Raport na temat petnego uczestnictwa Rzeczpospolitej Polskiej w Trzecim Etapie Unii Gospodarczo-Walutowej, Warszawa 2009, www.nbp.p1/Publikacje/O_Euro/RE1.pdf.

7 Por. Suplement. Kryzys finansowy i gospodarczy - implikacje dla integracji Polski ze strefa euro, [w:] Narodowy Bank Polski, Raport na temat petnego uczestnictwa Rzeczpospolitej Polskiej..., s. 372 i n.

${ }^{8}$ Pełnomocnik Rządu ds. Wprowadzenia Euro przez Rzeczpospolitą Polską, Bilans korzyści $i$ kosztów wprowadzania euro $w$ Polsce $w$ świetle najnowszych badań. Dokument uzupetniajacy do ram strategicznych narodowego planu wprowadzenia euro, Warszawa 2010, http://polskawue. gov.pl/files/polska_w_ue/Euro/bilans_10.2010.pdf, s. 24 i n.

${ }^{9} \mathrm{Z}$ sondażu, jaki wśród inwestorów, analityków, ekonomistów i traderów przeprowadziła w pierwszym tygodniu maja 2012 r. agencja Bloomberg wynika, iż 57\% jego uczestników uważa, że w tym roku co najmniej jeden kraj opuści strefę euro, jednocześnie $13 \%$ ankietowanych przewiduje, że strefa euro całkowicie się w tym roku rozpadnie, por. GS, Ankieta Bloomberga: Grecja opuści strefę euro jeszcze w tym roku, bezpiecznie jest tylko w Niemczech i USA, GG Parkiet z 11.05.2012 r. 
Materializacja tego czynnika ryzyka w sposób diametralny odmieni bilans korzyści i kosztów, a w skrajnym przypadku (powrotu przez kraje strefy euro do walut narodowych) zdezaktualizuje rozważania na temat obecności Polski w strefie euro.

\section{Harmonogram przygotowań do wprowadzenia w Polsce euro}

Szczegółowy harmonogram realizacji zadań w zakresie przygotowania do wprowadzenia w Polsce euro zostanie określony w Narodowym planie wprowadzenia euro opracowywanym we współpracy administracji rządowej i Narodowego Banku Polskiego. Pierwotnie opublikowanie tego dokumentu było przewidywane na III kwartał $2011 \mathrm{r}^{10}{ }^{10}$ Jednakże ani we wskazanym terminie, ani w późniejszym ${ }^{11}$ plan ten nie został opracowany. Natomiast 6 października $2011 \mathrm{r}$. odbyło się dziesiąte posiedzenie Rady Koordynacyjnej ds. Euro, na którym przedstawiciel Pełnomocnika Rządu ds. Wprowadzenia Euro przez Rzeczpospolitą Polską przedstawił założenia i strukturę Narodowego planu wprowadzenia euro oraz omówił procedurę dalszych prac nad dokumentem, w szczególności konsultacji $\mathrm{w}$ ramach struktury organizacyjnej ds. wprowadzenia euro w Polsce ${ }^{12}$.

$Z$ dotychczas opublikowanych dokumentów rządowych ${ }^{13}$ wynika, iż przygotowania do wprowadzenia euro w Polsce będą prowadzone w czterech etapach:

- etap I (przygotowawczy) - przed włączeniem złotego do ERM II;

- etap II (spełniania kryteriów konwergencji) - od momentu włączenia złotego do ERM II do decyzji Rady o uchyleniu derogacji;

- etap III (przygotowań technicznych do wprowadzenia euro) - od decyzji Rady o uchyleniu derogacji do momentu przystąpienia do strefy euro;

- etap IV (wprowadzenia euro) - wprowadzenie euro do obiegu i wycofanie z obiegu złotego.

W ramach pierwszego etapu, który formalnie trwa od uzyskania przez Polskę członkostwa w Unii Europejskiej w dniu 1 maja 2004 r., powinny zostać zidentyfikowane działania przygotowawcze, jakie należy podjąć we wszelkich sektorach gospodarki oraz w administracji państwowej i samorządowej. Ich przełożenie

${ }^{10}$ Por. Pełnomocnik Rządu ds. Wprowadzenia Euro przez Rzeczpospolitą Polską, Ramy Strategiczne Narodowego Planu Wprowadzenia Euro, Warszawa 2010, www.mf.gov.pl/_files_/euro/ raporty/rzadowe/4_ramy_strategiczne_26_10_2010.pdf, s. 6 .

${ }^{11} \mathrm{Tj}$. do dnia 14 maja $2012 \mathrm{r}$.

${ }_{12}$ Por. Ministerstwo Finansów, Dziesiąte posiedzenie Rady Koordynacyjnej ds. Euro, Aktualności, 10.10.2011, www.mf.gov.pl/dokument.php?const=1\&dzial=2903\&id=271603\&typ=news.

${ }_{13}$ Ministerstwo Finansów, Integracja Polski ze Strefa Euro: Uwarunkowania członkostwa i strategia zarządzania procesem, Warszawa 2005, www.mf.gov.pl/_files_/euro/raporty/rzadowe/1_integracja_polski_ze_strefa_euro_19_08_2005.pdf, s. 37; Ministerstwo Finansów, Mapa drogowa ..., s. 5; Pełnomocnik Rządu ds. Wprowadzenia Euro przez Rzeczpospolitą Polską, Ramy Strategiczne..., s. $71 \mathrm{i} \mathrm{n.}$ 
na zadania w poszczególnych obszarach, z ustaleniem podmiotów odpowiedzialnych za realizację i harmonogram, pozwoli opracować strategię działania ( $\mathrm{Na}$ rodowy plan wprowadzenia euro). Etap ten powinien zakończyć się najpóźniej na 32 miesiące przed planowanym wprowadzeniem euro ${ }^{14}$.

W drugim etapie zakłada się wypełnienie kryteriów konwergencji, zarówno fiskalnej - odnoszącej się do wielkości deficytu sektora finansów publicznych i długu publicznego, jak i monetarnej - dotyczącej stabilności cen, wysokości długoterminowych stóp procentowych oraz stabilności kursu walutowego w ramach europejskiego systemu walutowego ERM II (art. 140 ust. 1 TFUE). Niezależnie od powyższego na tym etapie powinna zostać osiągnięta konwergencja prawna ${ }^{15}$, w szczególności w zakresie: niezależności krajowych banków centralnych (art. 130 TFUE), przestrzegania zakazu finansowania ze środków banku centralnego (art. 123 TFUE), uprzywilejowanego dostępu do instytucji finansowych (art. 124) oraz integracji prawnej krajowych banków centralnych z Eurosystemem (art. 14 Statutu ESBC i EBC). Spełnienie kryteriów konwergencji stanowić będzie podstawę do podjęcia przez Radę Europejską decyzji o uchyleniu derogacji ${ }^{16}$ oraz decyzji o ustaleniu nieodwracalnego kursu wymiany ${ }^{17}$.

Trzeci etap, obejmujący techniczne przygotowania do wprowadzenia euro, trwa około pół roku. W jego trakcie następuje zabezpieczenie odpowiedniej liczby banknotów i monet euro, zaopatrzenie w nie banków komercyjnych (zaopatrzenie pierwotne) i jednostek sektora detalicznego (zaopatrzenie wtórne) oraz rozpoczęcie podwójnej ekspozycji cen ${ }^{18}$.

W ramach czwartego etapu, związanego z wprowadzeniem euro, kontynuowana jest podwójna ekspozycja cen, następuje wymiana banknotów i monet nominowanych w złotych na euro przez banki komercyjne, a następnie przez NBP. Etap ten kończy się od 6 do 12 miesięcy po wprowadzeniu euro ${ }^{19}$.

${ }^{14}$ Pełnomocnik Rządu ds. Wprowadzenia Euro przez Rzeczpospolitą Polską, Ramy Strategiczne..., s. 76.

15 Zgodnie z art. 131 TFUE każde państwo członkowskie zapewnia zgodność swojego ustawodawstwa krajowego, w tym statutu krajowego banku centralnego, z Traktatami i Statutem ESBC i EBC (Protokół nr 4 w sprawie Statutu Europejskiego Systemu Banków Centralnych i Europejskiego Banku Centralnego, Dz. U. C 115/230 z 9 maja 2008 r.).

${ }^{16}$ Stosownie do treści art. 140 ust. 2 TFUE po konsultacji z Parlamentem Europejskim i dyskusji w ramach Rady Europejskiej, Rada, na wniosek Komisji, decyduje, które państwa członkowskie objęte derogacją spełniają niezbędne warunki, na podstawie kryteriów określonych w ust. 1, i uchyla derogacje w stosunku do danych państw członkowskich.

${ }_{17}$ Zgodnie z art. 140 ust. 3 TFUE, jeżeli decyduje się, zgodnie z procedurą przewidzianą w ust. 2, o zakończeniu stosowania derogacji, Rada, stanowiąc jednomyślnie głosami państw członkowskich, których walutą jest euro oraz danego państwa członkowskiego na wniosek Komisji i po konsultacji z Europejskim Bankiem Centralnym, nieodwołalnie określa kurs, po jakim euro zastępuje walutę danego państwa członkowskiego oraz decyduje o innych środkach niezbędnych do wprowadzenia euro jako jednej waluty w danym państwie członkowskim.

${ }_{18}$ Pełnomocnik Rządu ds. Wprowadzenia Euro przez Rzeczpospolitą Polską, Ramy Strategiczne..., s. 76.

19 Ibidem. 


\section{Podsumowanie}

Polska z dniem uzyskania członkostwa w Unii Europejskiej uczestniczy równocześnie w Unii Gospodarczo-Walutowej jako państwo objęte derogacją traktatową. Oznacza to, że przejściowo pozostaje przy dotychczasowej walucie, ale jest jednocześnie zobowiązana, po spełnieniu kryteriów konwergencji, do przyjęcia euro jako środka płatniczego. O ile jednak Polska zobowiązała się do wprowadzenia euro, o tyle nie został określony termin takiej operacji, który zależy od tempa wypełniania kryteriów konwergencji. Równocześnie kryzys fiskalny w strefie euro, rzutujący ujemnie na stabilność Unii Gospodarczej i Walutowej, stanowi przesłankę zabezpieczenia interesu narodowego $\mathrm{w}$ ramach strategii wprowadzania euro, której integralnym elementem będzie harmonogram działań. Wiele argumentów natury politycznej, finansowej i gospodarczej przemawia za tym, iż pozostanie przy krajowej walucie do czasu wzmocnienia stabilności w strefie euro leży w polskiej racji stanu.

Uwzględniając aktualne uwarunkowania, należy wskazać, iż zakończenie pierwszego etapu przygotowań i określenie daty przyjęcia euro w Polsce będzie celowe po:

- ustabilizowaniu się sytuacji gospodarczej w państwach strefy euro: stabilizacji stanu finansów publicznych oraz sytuacji na rynkach finansowych, w szczególności na rynkach obligacji i walutowym, względnie „wyjście ze strefy euro" państw o najniższym poziomie konwergencji realnej;

- wykrystalizowaniu się sytuacji politycznej w kraju poprzez wyłonienie się większości parlamentarnej zdolnej do przeprowadzenia koniecznych zmian w Konstytucji Rzeczpospolitej Polskiej.

Do tego czasu, kontynuując politykę gospodarczą, mającą na celu wypełnienie kryteriów z Maastricht, w szczególności kryteriów fiskalnych, należy zrezygnować z określania terminu przystąpienia do mechanizmu stabilizacji kursu ERM II oraz terminu wprowadzenia euro jako prawnego środka płatniczego w Polsce. Wypełnienie nominalnych kryteriów konwergencji stanowi bowiem nie tylko przesłankę uchylenia derogacji i pełnego uczestnictwa Polski w Unii Gospodarczej i Walutowej, lecz także tworzy podstawy stabilności makroekonomicznej i finansowej, sprzyjając długofalowemu wzrostowi gospodarczemu i prawidłowemu funkcjonowaniu rynku finansowego. Jednocześnie wzrost konwergencji realnej zmniejszy czas i koszty przyszłych działań dostosowawczych przed przyjęciem euro oraz zagrożenia wynikające $\mathrm{z}$ tego procesu. 